\title{
SHADOWS OF THE PLANTATION? A SOCIAL HISTORY OF SURINAME'S BAUXITE TOWN MOENGO
}

\begin{abstract}
My father ... first worked as an indentured laborer at plantation Dordrecht. After his contract period, he went to look for a job to earn more. And he ended up all the way at Moengo. How did he know that there was work there? He had heard from others that you could earn lots of money at Moengo. At Dordrecht he earned fifteen cents an hour, at Moengo he could earn sixty cents ${ }^{1}$... At the time there was no regular boat connection, so he went with people who transported vegetables, rice, and fruit to Moengo ... When he arrived, he had to register as a rower for that merchant. And he couldn't go ashore. He had to stay in the boat at night ... It was wartime, and they watched those people closely. They were afraid of sabotage ... My father happened to know someone at Moengo who helped him with a pass ... And that's how he was able to go and register as jobseeker.
\end{abstract}

Mr. Kromo, retired Suralco-employee, interview in Paramaribo, July 2008

They first let you come over to get to know the place. I was there for three days, and it really made an impression, you know. They need me here, and it is so pretty ... And you earned so much more. In the city you'd earn 160 as a qualified nurse, but at Moengo you'd get 400 [a month, in 1950] ... If you had seen that little town; it measured up to a foreign city.

Nurse Fernandes, former director of the Moengo hospital and a Suralco staff member, interview in Paramaribo, August 2008

1. In 1943 a field laborer in Moengo earned 36 cents an hour and a mine or mill worker 38 cents an hour according to Lie a Kwie \& Esajas (1996:107). 
Bauxite has long been a major contributor to Suriname's GDP and the predominant foreign currency earner. ${ }^{2}$ Its importance to Suriname's economy is duly noted in macro-economic reviews. ${ }^{3}$ It has, however, hardly received attention in historical, sociological, or political studies on Suriname, let alone in studies of a more sociocultural character. ${ }^{4}$ How the mining enclaves of Moengo, Paranam, and Onverdacht functioned, what kind of social life and expectations they generated, and what impact they had on Surinamese society remains unexplored. Using oral narratives about life in the bauxite town of Moengo, as well as census and other statistical data, this article explores to what extent we can discern the shadows of the plantation in Suriname's mining enclaves.

Moengo was Suriname's first mining town; its history coincides with that of bauxite mining in Suriname. Because of its relative isolation and its almost exclusive reliance on the bauxite company, it developed into a company town with elaborate facilities and a unique social history. Moengo constituted a closed, insular enclave which could not easily be accessed and was for a long time highly regulated. Oral history narratives drew attention to the fact that the role of the Company, de Maatschappij, was far more than that of just a comparatively well-paying employer, but that it also took on the roles of a police officer, patriarch, and benefactor. They also indicated numerous continuities between the plantation and the mining town in terms of the labor regime and the kinds of socioeconomic and cultural spaces generated. Moengo's history incorporates many of the crucial changes in Surinamese society in the course of the twentieth century. It exemplifies the move away from a plantation economy, yet it also raises questions regarding underlying continuities. It is a recounting of how avenues for social mobility were opened, but also highlights how highly differentiated such opportunities remained.

Even though this article also makes extensive use of census data and other archival sources, it relies primarily on the life story/oral history interviews I conducted between 2006 and 2008 in the context of a research project on Suriname's twentieth-century social history. During the initial round

2. The research on which this article is based was conducted in the context of a larger collaborative project on Suriname's twentieth-century social history, with Rivke Jaffe, Hebe Verrest, and Rosemarijn Hoefte at the Royal Netherlands Institute of Southeast Asian and Caribbean Studies (KITLV). I am grateful to these colleagues for their support and insightful and encouraging advice. The Netherlands Organization for Scientific Research (NWO) generously financed the project. I also want to thank Ine Apapoe, Yoanne Najoe, Denice Gooding, and Reana Burke for their research assistance in Suriname. I am, however, most indebted to the many people who took the time to tell me their personal version of Suriname's twentieth-century history.

3. See, for example, Van Dijck 2001, 2005.

4. But see Hesselink (1974) and the commemorative volume by Lie a Kwie \& Esajas (1996), which was commissioned by Suralco. 
of interviews in 2006 and 2007 I conducted life story interviews with a broad range of middle-aged to elderly people from different social backgrounds and with different personal trajectories. These interviews started with questions about the place and date of birth, family background, and then followed the interviewees' lead as they recounted their lives. Even though most of the interviews took place in Paramaribo, the life stories of the interviewees covered most of Suriname's differentiated landscape: the districts, the interior, mining towns, and capital city.

From my initial round of eighty interviews, ten interviews discussed life in the mining industry (at Moengo or Paranam) at length. In July and August 2008 I conducted twenty additional oral history interviews with Moengonese in Moengo and in Paramaribo, which focused specifically on different aspects of their lives in the mining town, from people's migration and work histories to experiences of growing up in the company town, social relations and stratification, and Company rules and hierarchies to the impact of the Binnenlandse Oorlog (Interior War). Most of these interviews were with men, former Suralco employees of different ages, ranks, and ethnic backgrounds, but I also spoke to ten women who had grown up or lived in Moengo. Only one of these women actually worked for the Company itself, which reflects the highly skewed gender ratio of Company employment.

I conducted the bulk of these interviews in Dutch, and twice in Sranantongo. Two interviews were conducted by assistants in Aukaans, the Ndyuka Maroon language, while I was present and listened in. The interviews generally lasted one to three hours; in a number of cases I conducted follow-up interviews. I have replaced the names of most of my interviewees with pseudonyms.

In the following I first give a brief overview of Suriname's bauxite history. I then turn to Moengo's early period. Who came to work in the enclave and what positions did they find themselves in? Next, I discuss how the enclave was positioned in its wider surroundings. Even though Moengo was closed to anyone but Company employees and their families, it also became a regional center of sorts. In the next sections I turn to the rigorously gendered nature of Moengo's everyday life, and examine social hierarchies, order and discipline in the mining town. Oral history and other sources indicate that, even though discipline on the plant was rigorous, it was never stable but rather continuously contested and in the process of transformation. I end with some reflections on the length of the shadows of the plantation. How far did these shadows - the traces of the racially, hierarchically ordered plantation complex - reach into the social organization of that symbol of modernity, the company town? 


\section{PLANTATION ECONOMY PARALLELS}

Most Caribbean societies are characterized by extremely dependent economies in which large metropolitan or transnational companies engaged in resource production and extraction play major roles. These particular structures of dependency have deep historical roots in the Caribbean. Since its colonial inception, the area has been structured around limited metropolitan needs.

Plantation economy scholars focused on the ways in which the dominance of metropolitan enterprise impacted Caribbean economies and societies and was conducive to specific hierarchies, norms, and preferences, notably the conflation of race and class, a white bias, and a taste for metropolitan imports. ${ }^{5}$ As Norman Girvan (2006:336) succinctly recapitulates:

\footnotetext{
Plantation theorists argued that transnational corporations ended up draining capital from the local economy through repatriation of profits, and promoted dependency on imported intermediate inputs and on capitalintensive technology.
}

Girvan's work $(1970,1975,2006)$ highlights the similarities between plantations and mining enclaves, and, at a macro-economic level, economic structures dominated by either plantations or mining. Earlier political-economic structures, including economic dependence and underdevelopment, and racial hierarchies were seen to be reproduced in and through the mineral industry, in what Beckford (2000:253, 300) called "a 'ratooning' of the plantation system."

The shift from sugar to bauxite indeed did little to lessen Suriname's dependent integration into the global economy. Despite the crucial shift from large-scale agricultural enterprises to an agricultural sector dominated by small enterprises and the significant expansion of the government sector after World War II, Suriname's economy continued to depend on large-scale, foreign-owned resource exploitation companies (see Van Dijck 2001, Hoefte \& Meel 2001:xiv). To what extent can we discern similar continuities and parallels between the plantation and the mining enclave in terms of social organization and sociocultural stratification?

\section{SURINAME'S BAUXITE}

While in the late nineteenth century and first half of the twentieth century Suriname's sugar industry steadily declined, large bauxite deposits were discovered in the early twentieth century. Alcoa, already the major American

5. See, e.g., Best 2005 together with Levitt 1978, Beckford 2000, and Girvan 1970, 1975, 2006. 
bauxite company at the time, had contrived to acquire widespread concessions in areas where bauxite deposits were suspected. The terms under which the Surinaamsche Bauxiet Maatschappij (SBM; renamed Suralco in 1957), the Surinamese subsidiary of Alcoa, could operate were extremely favorable until the mid-1970s. These terms were repeatedly subject to debates in the Surinaamse Staten (the local parliament), but Dutch interventions restricted renegotiations (Lamur 1985).

In 1920 the SBM started mining bauxite at Moengo, the isolated location of what was once a Maroon village in the east of the country (Lie a Kwie \& Esajas 1996, Oudschans Dentz 1921). Over the years Moengo developed into a full-fledged company town. Adjacent to Moengo proper, a more informal, largely Javanese settlement came into being around 1930. Wonoredjo was declared an official village community in $1941 .{ }^{6}$ The number of inhabitants of Moengo/Wonoredjo grew from 2,687 in 1950, to 5,320 in 1964 and 6,633 inhabitants in 1971 (see Table 1). Mining soon came to dominate the otherwise sparsely populated district of Marowijne.

Table 1. Number of residents in bauxite towns*

\begin{tabular}{lrrr}
\hline Town & 1950 & 1964 & 1971 \\
\hline Moengo & 2,687 & 5,320 & 6,633 \\
Billiton & 923 & 3,126 & 2,721 \\
Paranam & 1,399 & 2,634 & 3,093 \\
\hline Total & 5,009 & 11,080 & 12,447 \\
\hline
\end{tabular}

Source: Census of 1950, 1964, and 1971.

* Because of changes in the enumeration districts between 1950 and 1964, and the different treatment of "bushland population" in all three years, the data are not fully comparable.

From the 1920s onward exports rose quickly, and in the 1940s Suriname became one of the largest producers of bauxite worldwide. While bauxite production and the number of employees showed great fluctuations over time, the overall trend was one of production growth. The economic crisis caused a temporary slump in production, and a reduction of the number of employees from 700 to 290 in the early 1930s (Lie a Kwie \& Esajas 1996:68), but by the late 1930s production had picked up, and in 1942 it reached unprecedented heights due to heavy demand from the U.S. war industry (ESWIN 1956:119, Lie a Kwie \& Esajas 1996:72). The number of people employed in the baux-

6. Verslag der Handelingen van de Staten van Suriname (Handelingen) p. 98 and Bijlagen (24.1-3). 
ite sector increased sharply, from 954 in 1939 to 2,634 in 1942 (Ramsoedh 1990:155, Surinaams Verslag 1940, 1944).

In 1939 SBM started developing another mining location, Paranam, upstream of Paramaribo on the Suriname River, where it was soon joined by the Dutch Billiton company, which developed operations at nearby Onverdacht. The center of Suriname's mining sector shifted from Moengo to Paranam/Onverdacht, even more so when a hydroelectric dam, an alumina factory, and an aluminum smelter, financed by Suralco in exchange for new bauxite concessions, were built at Paranam in the early 1960s (Lie a Kwie \& Esajas 1996:80). ${ }^{7}$ Both Paranam and Onverdacht developed into company towns, but they remained relatively small, as their proximity to the city allowed workers to commute from Paramaribo (see De Bruijne 1976:72-73).

Table 2. Distribution of mining personnel per district in 1964

\begin{tabular}{llc}
\hline District & Most likely employed at: & $\begin{array}{l}\text { \% of all employees in } \\
\text { mining sector }(\mathrm{n}=5570)\end{array}$ \\
\hline Marowijne & Moengo & 17 \\
Suriname & Billiton/Paranam & 43 \\
Paramaribo & $\begin{array}{l}\text { Billiton/Paranam, Paramaribo headquarters } \\
\text { and dam construction in Brokopondo }\end{array}$ & 28 \\
Brokopondo & Dam construction in Brokopondo & 10 \\
\hline Total & & 98 \\
\hline
\end{tabular}

Source: 1964 Census.

Due to its capital-intensive nature the bauxite sector remained a relatively modest source of employment. High capital investments allowed for increased production without concomitant increases in employment. While the mining sector provided between 5 percent and 8 percent of all employment in the years 1953-82 (Buddingh' 1995:310), in 2006 it employed merely 3 percent of the economically active population (Ferrier 2007:24). Yet since the industry is heavily dominated by men, these figures understate the importance of the mining sector as an employer for the male labor force: in 1964 it employed 10 percent of all employed men (ABS 1964).

In 1941 Suriname was the origin of 88 percent of American bauxite imports and in 1948 of 82 percent, but the country steadily lost that premier position with the rise of other, cheaper sources. ${ }^{8}$ Whereas in 1950 it still produced 30 percent of the world's bauxite, in 1991 Suriname's share had dropped to 3

7. Table 2 details the distribution of mining employees in 1964.

8. Minerals Yearbook (1941:656 and 1949:168), <http://minerals.usgs.gov/minerals/ pubs/usbmmyb.html>, accessed February 21, 2011. 
percent (Lie a Kwie \& Esajas 1996:244). In terms of Suriname's GDP, bauxite and alumina production remained paramount. From the 1930s onward, bauxite and bauxite products have represented the single largest export product and contributor to the GDP (Van Dijck 2001:57). While the relative importance of bauxite exports has decreased in the last two decades, extractive industries have taken on renewed importance due to the booming oil sector and more recently the large-scale mining of gold (Van Dijck 2001, 2005).

\section{A MiNING ENCLAVE IN THE JUNGLE}

Much-traveled Dutch civil servant and writer Fred Oudschans Dentz visited Moengo in 1919 or 1920, when only part of the settlement had been finished. He spoke enthusiastically of the founding of Moengo as "an adventure story, a piece of modern history and a monument to the willpower and perseverance of the Americans" (Oudschans Dentz 1921:485). He was clearly impressed by the U.S. accomplishments and the modern, all-encompassing organization of the production process, labor force, and village. The village that was created on the banks of the Cottica River, isolated in the jungle of Eastern Suriname, was designed for 1,000 workers, who "with women and children" would make up a population of 4,000 people (Oudschans Dentz 1921:486). According to Oudschans Dentz, the Americans implemented a wide-ranging and highly advanced sanitary infrastructure, using their experiences in other labor enclaves in tropical areas, such as Panama and Cuba. This infrastructure included a system for drinking water, indoor sanitary facilities and a sewage system, anti-malaria measures, and a hospital. There were advanced plans for a power station that would supply electricity to the town, the factory, and the water supply (Oudschans Dentz 1921:488-90). Moengo's modern infrastructure outshone that of the capital, as did, apparently, some of the company equipment. "Calculators are as yet unknown in Paramaribo, and typewriters are busily typing away in this small distant town in the jungle," writes Oudschans Dentz (1921:502).

From Oudschans Dentz's account we can conclude that Moengo's almost entirely male population of 474 consisted of 22 U.S. citizens and 57 "foreign whites," most likely French deportees (see Lie a Kwie \& Esajas 1996:48), as well as almost 300 Surinamese, some 50 workers from the British West Indies, and some 40 Javanese (Oudschans Dentz 1921:491). Oudschans Dentz mentions that the Company employed Amerindians as lumberjacks and had made arrangements with local Maroons for the supply of wood. SBM further employed some 150 carpenters, mostly hailing from Paramaribo. Regarding administrative jobs, he writes: "It goes without saying that a many people have found employment with the company, even if the leading posts remain in American hands ... Surinamese have never had similar opportunities for 
well-paid, subordinate posts. Now that these are available, they leave their scantily paid jobs in the private sector or with the government" (Oudschans Dentz 1921:502). According to Oudschans Dentz the wages at Moengo were significantly higher than those paid in other sectors and companies.

Indentured laborers from the Netherlands East Indies made up a significant part of Moengo's early workforce. The SBM concluded a contract with the government for 400 "Javanese" laborers (Lie a Kwie \& Esajas 1996:45). Between February and August 1920 three ships carried 251 laborers who had signed five-year contracts to work at Moengo (Burside 1986:5). Little is known about this group of indentured laborers who, instead of signing up for work at one of Suriname's plantations, ended up in the newly established mining enclave. The digitized Immigration Register contains the records of 110 of the laborers who were contracted to work at Moengo: 51 women and 59 men. ${ }^{9}$ These included at least 9 young children, including the later political leader Salikin Hardjo (Bruinessen 2001). It is striking that most indentured laborers were in their twenties or early thirties and that many were married and came with their partners. It seems that the Company had specifically requested married couples, hoping they would make for a reliable and possibly self-reproducing workforce. Oudschans Dentz (1921:504) does indeed mention such a Company policy, and according to Hoefte (1998:108), government policies similarly promoted the recruitment of married couples as indentured laborers.

Salikin Hardjo's father arrived in Suriname in 1920 after he had signed a five-year contract to work as a mechanic at Moengo. His story gives a glimpse into early life at Moengo. Hardjo's father followed the example of a friend who had been contracted to work as an electrician at Moengo (Bruinessen 2001:6). The two friends were hired as skilled laborers, which was exceptional. Most of Moengo's indentured laborers were involved in manual occupations: in the mining, transport, and washing of bauxite, as well as the upkeep of the enclave's vegetable garden (see Hesselink 1974:60, Lie a Kwie \& Esajas 1996:49). "The company was very satisfied with the Javanese laborers," Lie a Kwie and Esajas (1996:49) note. "Not only were they brought into action in the vegetable garden, but they were also excellent miners, while the women were skillful in washing bauxite." While the experiment with indentured labor was not continued, the manual labor force would continue to be dominated by Javanese, predominantly ex-indentured laborers from plantations in the neighboring district of Commewijne.

Mr. Ernst was in his late 80s when I interviewed him in Paramaribo in 2008. He lived at Moengo off and on from the late 1920s onward and was one of the few who still remembers what life was like in Moengo before World

9. The Madioen II, which carried 151 of Moengo's indentured laborers, has been omitted from the digitalized Immigration Register, available at http:/www.nationaalarchief. nl/suriname/base_java/introductie.html; last accessed December 24, 2010. 
War II. "In those days you had to go to Moengo by boat, the Paramaribo," he says. "You had one twice a week. So Moengo was an isolated place for those workers, you had nowhere to go. That's why the Americans always ensured the good life there in Moengo." He says that there used to be an Ons Belang, a store selling produce from the Company-owned farm. "Everything belongs to the Company. You could go get [your groceries] with a ticket with a number. And every fortnight, they would deduct that from your salary."

Moengo was initially set up in different neighborhoods for different racial groups: a spaciously laid-out American Quarter and smaller quarters for Surinamese and Javanese laborers (Oudschans Dentz 1921:487). According to Mr. Ernst, "In the old days, there used to be a separate quarter for the foremen. Sranan Kwatta, Surinamese Quarter in American ... Common laborers lived on the plant itself." Hardjo's account of his early years at Moengo corroborates Mr. Ernst's description:

On arrival in Moengo the artisans were assigned single-family homes, while the uneducated had to live in long barracks. Since Hardjo's father and his friend Saman were registered as a mechanic and an electrician, they were each assigned such a nice house. "Our house was much better than the one in Java, it was an elevated house," said Salikin Hardjo. "I liked it there, but there were no children. Javanese children were at the other side, near the barracks. And Negro children lived two kilometers further" (Bruinessen 2001:10).

It seems that Hardjo and his family were housed in the Surinamese Quarter, which was reserved for skilled laborers and was set apart from the barracks that housed unskilled laborers. Unskilled laborers were apparently subdivided by race.

Mr. Ernst grew up in a so-called bunkhouse, one of those barracks mentioned by Hardjo, which were subdivided into rows of one-bedroom houses. They were called dyaris, yards, and each complex was known by its own name. "You had Bigi Dyari, Ala Dyari. The rows of Bigi Dyari formed a square, with in the middle two bathrooms, four toilets, and two water faucets." Most workers lived in such bunk housing, but Javanese mostly lived in Wonoredjo, he says. I ask him about social distinctions in his youth.

In those days it was a special kind of arrangement. Staff is staff, ${ }^{10}$ monthly is monthly, weekly and then the workers ... You couldn't go to where the big staff, Deputy Director Barnett, lived. As boys we also didn't go to

10. Staf was used to mean the upper echelons within the Company, the managerial staff. In this article I employ a literal translation of the term, staff, since I feel this does most justice to the original usage. 
Sranan Kwatta to play ... You could go there to run an errand, maybe you worked for one of those people there.

Oudschans Dentz (1921:490) mentions that the hill on which Moengo was located bordered on a swamp that was going to be drained and the reclaimed land would be made available to Javanese laborers who had completed their contracts. It seems likely that the Company wanted to create a partly selfsustaining pool of labor adjacent to the Company-owned town. This piece of reclaimed land is possibly the origin of the Javanese village of Wonoredjo, Moengo's informal shadow settlement. Some of Moengo's indentured laborers may have been Wonoredjo's founders.

The archives give an impression of the indentured laborers' opportunities for intergenerational social mobility. The Immigration Register includes the record of Bok Soeto, a female indentured laborer from the Semarang district in the Netherlands East Indies who came to Suriname on the Rotti III in 1920 to work at Moengo. In 1921 she gave birth to a son, Julius Doelgani, who, according to the 1950 census, would become SBM's telegraph operator. ${ }^{11}$ Consider also the case of Hendrik Soepeno, who was born in 1922 as the son of another of Moengo's female indentured laborers. In 1950 Soepeno was a Company clerk who had the rank of maandloner, ${ }^{12}$ which was exceptional among Javanese employees at the time.

\section{FROM THE PlANTATiON TO THE Mine}

While plantation agriculture continued its steady decline, bauxite replaced sugar as Suriname's major export product. As the demand for bauxite grew in the United States in the late 1930s and the SBM raised bauxite production accordingly, Moengo's population began to grow rapidly. Part of Moengo's workforce hailed from the fledgling plantations, where wages were low, and were lowered even more during the crisis years (Ramsoedh 1990:23-24).

Only the few large-scale agricultural enterprises that were able to introduce the technological innovations required to compete on the world market managed to operate well into the twentieth century. The largest and most significant of these was Mariënburg, a vast plantation with one of the largest, and, at the time, most modern sugar factories in the hemisphere. It relied heavily on cheap labor supplied by indentured laborers from the Dutch East Indies (see Hoefte 1998). In 1918 Marienburg's division of labor and con-

11. Nationaal Archief, Volkstelling Suriname 1950, nr. 2.10.19.02.

12. Maandloners or maandgelders were the second-ranking stratum of employees, also called monthly, since they were paid on a monthly basis. See p. 21 for a full explanation of terms related to the Company hierarchy. 
comitant hierarchies had a clear racial character. Its managerial staff was largely Dutch (and white), while the middle group of overseers was made up of Dutch and Creole men. The skilled laborers were a diverse intermediate group, again consisting of both Dutch and Creole men, though, as Hoefte notes, Javanese and Hindustani men increasingly joined their ranks as clerks from the 1920s onward. ${ }^{13}$ The manual labor force consisted almost exclusively of Javanese indentured laborers, men and women (Hoefte 1998:95).

Mr. Spalding grew up at Mariënburg in the late 1930s and 1940s as the son of a Guyanese sugar boiler and a Surinamese teacher. "At that prosperous time, Mariënburg was the second city after Paramaribo," he says. "It was a flourishing sugar enterprise." It paid very badly, but "Javanese were known to be satisfied with little." With obvious admiration, he recounts how some were able to acquire a Zündapp scooter, although they "hardly had food on the table." And they would proudly display their scooter on the veranda of their house. Mr. Spalding told me that field laborers lived in small bunkhouses. The luxurious staff housing was located away from workers' quarters, separated by a canal, and was off-limits to ordinary workers.

Mr. Spalding decided to become a sugar boiler like his father, thereby breaking with the tradition of hiring expat Guyanese for the position. "It was attractive," he says, "since staff members were regarded highly at Mariënburg. Its staff club was comparable to the Officer's Club in Paramaribo. It was even more modern, more beautiful." After having worked at Mariënburg for some ten years, he left Suriname's fledgling last sugar plantation in the mid1960s for a job in the potroom at Paranam.

Mr. Spalding was not the only one to leave the plantation for the betterpaying mining companies. Many overseers left Mariënburg to work in the bauxite industries from the 1930s onward (Hoefte 1998:99). Field laborers also started to leave the plantation for the mines. For all concerned, the move seems to have meant a significant improvement in wages and facilities. The drift away from the plantation continued until Mariënburg's by then antiquated sugar factory was finally closed in the mid-1980s.

Mrs. Marijke recounts the history of her parents, both children of Javanese indentured laborers, born "on plantation," as Surinamese say. Like Mr. Kromo's father and many other ex-indentured laborers, Marijke's father left the plantation in the 1950s to look for a better-paying job. Mrs. Marijke

13. Suriname is perceived as consisting of a number of bevolkingsgroepen, population groups, of a predominantly ethnic nature. The main groups are Creoles (descendents of enslaved Africans who often also claim more mixed origins), Hindustanis (descendents of East Indian indentured laborers), Javanese (descendents of indentured laborers from the Netherlands East Indies), Maroons (descendents of enslaved who fled the plantations), Amerindians, and Chinese (for an extensive discussion of ethnic categories in Suriname, see De Koning 2011a). 
remembers the holidays she spent with her grandparents on plantation Zoelen, which was part of the larger Mariënburg complex. She says she only later realized how hard life on plantation had been: the lack of clean drinking water and decent wages, and widespread poverty. "A Javanese woman was lucky if she was employed as a servant or cleaning lady in someone's house, at the plantation owner's. That meant you were well off. My parents weren't in such a favorable position. All this changed when my father had the chance to work as a laborer at Suralco." Her parents began their life as a married couple at Mariënburg, where her father had a job cutting and carrying cane. He did not like it, she says, and went to Paramaribo to look for work. A friend of his told him to come to Moengo.

Mr. Esajas's story reflects another typical trajectory. Mr. Esajas left his native Coronie during the war because he was drafted for the Schutterij, the National Guard. After the war ended, he found work at Moengo. "He started out earning 28 cents an hour," his wife remembers. It was slightly better than what he would earn in the city, she says, "but if you found something in the city, you stayed." Like many other new workers, Mr. Esajas started out "weeding," which meant hard physical labor clearing the concession grounds of overgrowth. Depending on one's performance, one was picked out by a manager of one of the departments. "He could not have been there more than a week, and an American passed by who saw him at work. He called his boss and said, 'Can you give me this man? I could use such strong fellows in the mine.' And that's how he went to the mine."

The Company mainly employed "Creole" and "Javanese" men, ${ }^{14}$ who made up some 80 percent of the workforce in the 1960s and 1970s. The remainder was made up of "Hindustanis," "[Amer]Indians," "Europeans," "Chinese," and diverse "Others" (Table 6) ${ }^{15}$ Moengo's demographics reflect the composition of the workforce. In 1964 the combined population of Moengo and Wonoredjo was made up of 48 percent "Creoles" and 42 percent "Javanese" (Table 3). In 1950, 62 percent of the 1950 Creole population over fifteen was born in Paramaribo, 10 percent in Marowijne, and 9 percent in Commewijne (see Table 4). In contrast 59 percent of all Javanese over fifteen had been born in the Netherlands East Indies and 24 percent in the Commewijne district, which included a large number of people from plantations Mariënburg and Alliance (see Table 5). While most of Moengo's adult

14. I use quotation marks to highlight the fact that these are census categories that univocally categorize a much more complex reality. Not only does such categorization privilege ethnic provenance as a stand-alone explanatory factor, it also assumes that discrete ethnic identities exist, and thereby categorizes mixture out of existence (see De Koning 2011a). 15. In 1964, 49 percent of the workforce was "Creole" and 37 percent "Javanese" (compared with a share of 36 percent and 14 percent in the national population) (Table 6), in 1970 both made up 39 percent (Table 7). 
Table 3. Population of Moengo and Wonoredjo in 1950 and 1964 by gender and ethnicity

\begin{tabular}{|l|r|r|r|r|r|r|r|r|r|r|r|r|r|r|r|r|}
\hline $\begin{array}{l}\text { Race/ } \\
\text { Ethnicity }\end{array}$ & \multicolumn{2}{|c|}{$\begin{array}{l}\text { Black/Col. } \\
\text { Creole }\end{array}$} & \multicolumn{2}{|l|}{ Hindustani } & \multicolumn{2}{|l|}{ Javanese } & \multicolumn{2}{|c|}{ Chinese } & \multicolumn{2}{|c|}{$\begin{array}{l}\text { Amer] } \\
\text { Indian }\end{array}$} & \multicolumn{2}{|l|}{ European } & \multicolumn{2}{|c|}{ Other } & \multicolumn{2}{|c|}{ Total } \\
\hline Year & 1950 & 1964 & 1950 & 1964 & 1950 & 1964 & 1950 & 1964 & 1950 & 1964 & 1950 & 1964 & 1950 & 1964 & 1950 & 1964 \\
Male & 667 & 1255 & 67 & 185 & 576 & 1145 & 14 & 32 & 24 & 103 & 11 & 36 & 17 & 13 & 1376 & 2769 \\
Female & 635 & 1121 & 56 & 158 & 558 & 1099 & 8 & 27 & 28 & 99 & 16 & 33 & 10 & 14 & 1311 & 2551 \\
Total & 1302 & 2376 & 123 & 343 & 1134 & 2244 & 22 & 59 & 52 & 202 & 27 & 69 & 27 & 27 & 2687 & 5320 \\
\hline $\begin{array}{l}\% \text { of } \\
\text { population }\end{array}$ & $48 \%$ & $45 \%$ & $5 \%$ & $6 \%$ & $42 \%$ & $42 \%$ & $1 \%$ & $1 \%$ & $2 \%$ & $4 \%$ & $1 \%$ & $1 \%$ & $1 \%$ & $1 \%$ & $100 \%$ & $100 \%$ \\
\hline
\end{tabular}

Source: Census of 1950 and 1964.

Table 4. Birthplace of Creoles over 15 at Moengo/Wonoredjo in 1950

\begin{tabular}{lr}
\hline Place of Birth & $\%$ \\
\hline Paramaribo & 62 \\
Marowijne district & 10 \\
Moengo 2\%, Albina 2\% & \\
Commewijne district & 9 \\
Nickerie district & 6 \\
Suriname district & 4 \\
Coronie district & 5 \\
Abroad & 3 \\
\hline Total & 99 \\
\hline
\end{tabular}

Figures based on a representative sample of 1950 census data.

Table 5. Birthplace of Javanese over 15 at Moengo/Wonoredjo in 1950

\begin{tabular}{lr}
\hline Place of Birth & $\%$ \\
\hline Netherlands Indies & 59 \\
District Commewijne & 24 \\
Mariënburg 7\%; Alliance 4\% & 3 \\
Moengo & 8 \\
Suriname district & 2 \\
Paramaribo & 2 \\
Nickerie district & 98 \\
\hline Total
\end{tabular}

Figures based on a representative sample of 1950 census data. 
Creole population thus came from the city, a vast majority of the Javanese at Moengo (some 85 percent) seem to have moved from the plantation to the mine, perhaps with a short spell during which they worked in town or had been drafted for military service during World War II. Though geographical proximity played a role, it was particularly the longstanding dominance of plantations and the poor salaries and working conditions they offered Javanese (ex-indentured) laborers that made Commewijne into the primary supplier of unskilled labor to the SBM.

In 1970 Hesselink (1974:72) found that most Javanese employees were children of plantation laborers or peasants, while over half of their Creole colleagues were children of low-level civil servants or artisans. Almost a quarter of the uurloners and weekloners were natives of Marowijne. This indicates that by that time a considerable number of sons of Suralco employees had taken jobs in the Company, reflecting the Company's preference for family members of employees (Hesselink 1974:72), and indicating the importance of the Company as a facilitator of intra- and intergenerational social mobility.

\section{A BETTER LIFE}

I asked Oma how she liked life in Moengo. She said it was like paradise, so tidy. An appreciation of the clean and orderly life in Moengo was common among the people I spoke with (see Hesselink 1974). It often meant the move from a hut made of palm leaves or a small yard-house to first a bunkhouse and later a stone house. Life was cheap because Company housing was inexpensive, electricity and water were free. One could even get loans to build a house in Paramaribo. The Company took care of every minute detail on the plant, even replacing burnt-out light-bulbs.

For people from the plantations, Company employment presented an escape from poverty and hard, poorly paid labor. "Did people think highly of a job at Suralco?" I asked Oma, an elderly lady married to a retired Suralco laborer, who herself had worked as a maid for Suralco staff.

Well yes, you didn't earn that much, but earlier at Mariënburg, you earned 1 guilder a week; now you are at Moengo and you earn 25, 20 guilders a week ... My husband was a carpenter at Mariënburg ... In 1949 he went to Moengo where he found work as a carpenter again. Then he received 18,50 per week ... My husband says, the Suralco is mistaken. So he put ten guilders aside. Afraid that they would come back for it? Yeah ... Until one day he asked a friend. Isn't the Suralco making a mistake? Because I get 18 guilders every week. Then this friend says, No, this is what you earn. 
Such favorable comparisons between plantation and Suralco wages were common in oral histories of Javanese Moengonese. While Sf 18.50 seems a reasonable estimate of a starting wages for common laborers at Moengo, wages at Mariënburg must have been higher than one guilder a week. Mr. Kromo's quote of 15 cents versus 60 cents an hour seems more realistic (see also footnote 1). However, Oma's narrative serves to highlight the perceived stark contrast between the two.

The comparative value of Moengo wages remains a moot point. Oudschans Dentz mentions the relatively generous wages in Moengo's early years and Lie a Kwie and Esajas (1996:74) argue that in the 1930s, Moengo employees were the highest paid in the country. Longstanding Moengonese Mr. Ernst confirms this. "Moengo employees earned well," he says. "That's why, when the Paramaribo [the boat that shuttled between Moengo and Paramaribo] came from Moengo, you see all those women eyeing those Moengo-men. Yes, they come with money." Yet Staten debates and severe labor unrest in 1941-42 indicate that even in the mining sector, wages were hardly sufficient (see De Koning 2011b). Even if wartime inflation accounted for part of the hardship, several of my interlocutors pointed out that wages remained modest in the postwar years. They were hardly enough to comfortably feed a family; many Moengo women supplemented their husband's Company wages with home-based economic activities.

In 1942 mining unions were founded at Moengo and Paranam after a grim standoff between the Company and Moengo workers (see De Koning 2011b). Moengo has had a high degree of labor organization ever since, which over time yielded important gains in terms of wages and fringe benefits. In 1961 the mining sector paid the second-highest average wages in the country, Sf 3,459 per annum, as compared to, for example, Sf 1,924 in the trade sector. ${ }^{16}$ By 1973 average wages in the bauxite sector were the highest nationally, Sf 10,000, as compared to the average wage of Sf 5,730 in the transport and communication sector, the second-best paying sector (Van Schaaijk 1975:24).

Moengo offered extensive facilities and primary and later secondary schools that were said to be of high quality. Over the years, Company employment became increasingly secure and, from the 1950s onward, offered additional benefits like retirement packages, mortgage facilities, as well as scholarships for the children of employees. In addition there was a policy of preferential employment for born-and-bred Moengonese. Moengo thus provided significant avenues for intra- and intergenerational social mobility. I was told that many Moengo children had gone on to successful professional careers.

Stories like those of Mr. Spalding and Mrs. Marijke illustrate many of the links and continuities between the plantation and the mining enclave. To staff, skilled workers, and laborers alike, the switch to the mine meant sig-

16. Source: Bedrijfs- en beroepstelling (1961:4). 
nificant improvements in income and facilities. However, they encountered a strikingly similar hierarchical society and were allotted largely similar positions in occupational and social hierarchies.

\section{NEIGHBORS AND EMPLOYEES}

Moengo is located in the rugged Marowijne district surrounded by small Ndyuka Maroon villages, without any towns in the vicinity. A ten-hour, twiceweekly boat service provided Moengo's major connection to Paramaribo until the East-West Corridor was completed in 1964. Even though the road lessened Moengo's isolation, its distance to the city remained considerable, in part because it could not be reached without crossing two rivers by infrequent ferries.

The Moengo enclave consisted of Moengo plant, the highly regulated and stratified company town that boasted an excellent infrastructure, and Wonoredjo. Wonoredjo's village community status meant that a village council headed by the village headman, the lurah, held communal title to the land, was responsible for village affairs, and had to answer to the District Commissioner (Ramsoedh 1990:112-19). While these parts were each organized in distinct, even contrasting ways, they had a complementary, even symbiotic existence. Moengo proper housed only Company employees and government personnel, while Wonoredjo also housed casual laborers, pensioners, and cleaning ladies (Hesselink 1974:65). Even though Wonoredjo had a largely Javanese population (88 percent in 1950), it also housed some Chinese and Creoles. Most non-Javanese who could not or would not live on the plant lived on the Bursideweg, at the edge of the bauxite concession, or across the river in Abraliba. Mr. Kromo, who was born and raised in Wonoredjo, reflects on the symbiotic relationship between Moengo and Wonoredjo:

\footnotetext{
Wonoredjo was Moengo's vegetable garden ... Many of those men [in Wonoredjo] were employed by the SBM, the women stayed at home. In the morning they have that tengo, that basket, full of vegetables, cassava and so on ... and they go to Moengo to sell door-to-door. Suralco does import vegetables twice a week, but that's not enough. That's why they buy from those Javanese women. In the morning you'd have a row of some ten to twenty women walking along the footpaths in the direction of Moengo, and by nine they'd have made all their money for that day. Then they get back to work planting and harvesting.
}

The Company had a fixed core of permanent workers over whom it exercised a large measure of control because they lived on Company grounds, while it could also draw on a large labor reservoir at Wonoredjo and the surrounding 
Maroon villages for work of a more temporary nature. The advantage was that laborers from Wonoredjo and the villages did not require investment in infrastructure and facilities, nor did they entail economic and social responsibilities (Hesselink 1974:64-65). Wonoredjo had nothing like the infrastructure or facilities of Moengo proper, but was also largely free of the Company control ubiquitous in Moengo proper. It was presided over by the lurah, who acted as an intermediary between the government and the villagers and had an important say in village affairs, not least because he administered the use rights to the village grounds (see Ramsoedh 1990:112-13). Wonoredjo housed a number of small restaurants, bars, and shops, which were not allowed on the concession grounds and for many Moengonese presented a welcome escape from the more regulated Moengo plant.

The Company had a strict policy regarding Moengo's other neighbors, Maroons from nearby villages along the river and later along the road. As Mr. Ernst remembers, Maroons did not live at Moengo in the old days. "They came to sell things and wash clothes for people. But then after five they had to leave again," he says. Mr. Kromo corroborates: "At five o'clock, they had to go down the river." 17 At least until World War II, SBM did not directly employ Maroons. This might have been deliberate Company policy to keep control of movements in and out of the enclave.

Among the first Maroons who were hired by Suralco were men from the village of Tamarin, located 30 kilometers downstream from Moengo along the Cottica River. Tamarin was the center for mission activities in the Cottica area and was seen as pati dyali, the priest's yard, says Mr. Witkamp, who was born there in the 1950s. In its heyday it had a sawmill, a boarding school, and of course a church, as well as a policlinic, a store, and a service station. It attracted people of different backgrounds who were employed by the mission, recounts Mr. Witkamp: "All sorts of teachers came and stayed - Hindustanis, Javanese - and their wife and children would join them. The sawmill was run by a half-Chinese, boss Harry Chin. So you had all sorts, it was not really a Maroon village."

Mr. Witkamp says that the mission sawmill lacked a competitive edge; moreover, certain kinds of timber became scarce and difficult to log. A big fire in the Cottica area in the mid-1960s put an end to the logging industry at Tamarin. Suralco commissioned poultry farming, most likely at the local priest's behest. 'If you wanted to participate in the poultry farming, you'd get all the material, instructions and sell the eggs to Suralco ... Really, for me as a young boy, I saw eggs, eggs, and more eggs." There was also a joint Suralco/ government project to grow citrus fruit. But, Mr. Witkamp says, those were also destroyed in the fire. Other top-down experiments with rice cultivation and tilapia farming initiated by the ministry of agriculture also failed. "What about the chickens?" I asked. Well, the chickens were no success story either.

17. Emphasis added to indicate that this part of the sentence was originally in English. 
Tamarin's days as a lively village community were over. "When the logging was no longer going well, more and more people went to Moengo to find a job ... As a young boy [i.e. in the early 1960s] I saw the shift when people left the sawmill to work for Suralco."

According to Mr. Westerman, son of one of the pioneers from Tamarin, his father and uncles were hired by the Company in the mid-1950s because they were such able soccer players. After work, soccer was the most important activity at Moengo. Teams that represented different Company departments would vie to hire talented players like Mr. Westerman's father and uncles. "People from Tamarin adapted easily to life here [at Moengo], because they had already encountered Western life. Tamarin was not a traditional village," Mr. Westerman says. He himself was born in Moengo in the late 1950s and grew up among Javanese and city Creoles. He remembers seeing the number of Maroons at Moengo increase slowly. "They were hired for the maintenance of the town, or the track. They'd get those kinds of jobs, you know, because that was really hard work, and in general they were really strong, because of their gardens."

Mr. Witkamp recounts how many ordinary laborers started out: "You don't work for Suralco straightaway; you start working for a contractor, Mr. Tuinfort, Tonki ... Then the Suralco observes you and says, 'Him I want."' Mr. Kromo, who worked as a Company clerk, says the Company started working with casual labor through "contractor boss" Tuinfort in 1950. Tonki would not give his workers a break. "That man was a terrible fellow," he says. "When you are weeding and you stretch your back for a moment, he says, 'No, that's not the way we work, mi mus si yu gogo, I must see your behind." Mr. Witkamp has similar stories about this notorious boss: "Tonki says: 'Your soul belongs to God, but a skin na fu mi [your body belongs to me]' ... I have experienced the man ... If you work for Tonki you lose your pride ... You had to undergo a kind of baptism, the Tonki-baptism [laughs heartily]." Mr. Witkamp's uncle was the first from Tamarin to work at Moengo. Even though he also started with Tonki, he was able to rise through the ranks, says Mr. Witkamp: "He made it all the way to foreman with a white helmet. When you have a white helmet at the Suralco, you're almost black staff ... You are from Tamarin, from plantation, and you have a white helmet, and you have Maroons and Javanese and city Creoles working under your command."

\section{GENDERED DIVISIONS OF LABOR}

Life at the mining enclaves was marked by a highly gendered division of labor. With few exceptions, women at Moengo were either wives or daughters of employees. In Moengo's early days Javanese women had been involved in part of the production process, loading carts and washing the mined bauxite 
(Lie a Kwie \& Esajas 1996:132). The involvement of women in the primary production process seems to have been phased out with further mechanization. Moengo's core business soon became a male affair, notwithstanding the handful of women who did administrative work for the Company, the few female cooks and cleaning ladies in Company employment, as well as a the few female teachers and nurses stationed at Moengo. In 1964 the mining sector in Marowijne employed 915 men (95 percent) versus a mere 44 women (Table 6).

Table 6. Composition of the labor force in the mining sector in the Marowijne district in 1964 by gender and ethnicity (excluding unemployed)

\begin{tabular}{|l|c|c|c|c|c|c|c|c|}
\hline Race/ Ethnicity & $\begin{array}{c}\text { Black/Col. } \\
\text { Creole }\end{array}$ & Hindustani & Javanese & Chinese & [Amer]Indian & European & Other & Total \\
\hline Male & 436 & 60 & 343 & 6 & 34 & 15 & 21 & 915 \\
Female & 29 & 1 & 11 & 2 & 1 & 0 & 0 & 44 \\
Total & 465 & 61 & 354 & 8 & 35 & 15 & 21 & 959 \\
\hline $\begin{array}{l}\% \text { of total } \\
\text { employed }\end{array}$ & $48.5 \%$ & $6.4 \%$ & $36.9 \%$ & $0.8 \%$ & $3.6 \%$ & $1.6 \%$ & $2.2 \%$ & $100 \%$ \\
\hline
\end{tabular}

Source: 1964 Census.

While most female Moengonese were housewives, oral evidence indicates that many supplemented their family's income with low-paid service work, especially cleaning, or home-based economic activities like the production and sale of food and sweets. Mrs. Esajas, wife of the SBM employee from Coronie who moved to Moengo in the late 1940s, contributed to the family income with her sewing. "Many women did something," she says. "Others sold things to earn something extra. Others ironed clothes." Women in Wonoredjo contributed to the family's standard of living by planting vegetables for their own use and for sale; some also worked as maids for the better-off on the plant.

Quamina indicates that at Mackenzie, Guyana's bauxite town, the Demba Company actively encouraged stable, nuclear family life and discouraged extramarital affairs (1987:28-29). Suralco seems to have followed similar policies to promote nuclear household formation with a male breadwinner, as it almost exclusively employed men and there were very few other employment options at Moengo. According to the former female director of Moengo hospital, Suralco as a rule did not employ married women until the mid-1960s, when it changed its policy and retained their services even after they were married. Moengo's women were thus almost by default housewives. Several informants claimed that the Company preferred married men and facilitated their married life in terms of housing. Company facilities like single-family housing and the 
extension of numerous job-related facilities to the nuclear families of employees must have helped reproduce the nuclear family model.

In 1950 significantly more Moengonese were married and fewer were single as compared to Paramaribo (Table 8). Also the lower number of economically active women in Moengo indicates that Company policies did indeed result in nuclear household formation with a male breadwinner to a larger extent than in Paramaribo (87 percent of the women at Moengo were listed as economically inactive, versus 67 percent in Paramaribo).

Moreover, much of Moengo's public social life revolved around men. Except on special family occasions, the clubs were a male domain. Soccer, Moengo's favorite pastime which structured much of the remaining spare time and social life, was entirely male, as was for a long time the case for the somewhat secretive friendly societies, locally known as Courts, to which many employees belonged (see Hesselink 1974:84-85). Women were at home with the children, I was told, and it was a woman's task to facilitate her husband's work life. However, work routines structured the lives of women almost as significantly as those of their men. Food had to be ready in time for transport to the mine, and when father came home, the children had to be kept quiet so as not to disturb his rest. It is telling that the food delivery car was a central meeting point for Moengo's women.

\section{DISCIPLINE AND CONTROL IN THE COMPANY TOWN}

The stability and discipline of Moengo's labor force were secured not only through higher wages, relatively ample facilities, and the promotion of nuclear family formation, but also through restrictions on movement to and from Moengo. Even if the town's location played a key role in this respect, Moengo's isolation was actively policed by Company policy. Until 1945 one had to have a pass to visit Moengo; until 1964 visitors were not allowed to stay for more than two weeks and were submitted to a medical examination upon arrival (Hesselink 1974:54). "You had to come with a pass," Mr. Ernst remembers. "If I worked there, and you wanted to come, I'd have to go notify them ... You have to get checked out, even if you come on holidays. Yes, that's how strict they were." Even when such official restrictions were abolished, it was understood that one could not host guests for longer periods without the Company's approval (Hesselink 1974:54). Controls were probably not as tight in Wonoredjo, but according to an informant even there one had to notify the lurah of the presence of guests and the intended length of their stay.

Moengo's relative isolation and the fact that almost everyone in and around Moengo depended on the Company gave it an inordinate amount of power. If you did anything that went against Company rules, you could be summarily fired and put on the first boat to Paramaribo, as Mr. Kromo liked to 
emphasize: "down the river." The Company would forward your belongings. Upon further questioning, it appeared that such sanctions had been extremely rare, yet they clearly served to shore up labor discipline and compliance.

At Moengo, social position was directly linked to the position one held within the Company. Strata were designated by mode of payment - monthly, weekly, or hourly. Suralco distinguished members of the staf, i.e. managerial staff, from the tier of employees known as maandgelders, employees who were paid on a monthly basis. The latter stratum consisted of professionals, overseers and an elite of skilled workers. These were again set apart from the weekloners and uurloners, made up of skilled and unskilled laborers whose wages were calculated by week or by hour. Such stratification and the way it was institutionalized echoed the social divisions and hierarchies at the sugar plantation complex Mariënburg.

Moengo's division of labor and the related social hierarchies long married race to class in no uncertain terms. Until after World War II, professional/staff positions were only open to whites (Hesselink 1974:52). And even after the race criterion was formally abandoned, the demand for specific metropolitan qualifications, for instance an engineering degree, ensured a large measure of continuation of this conflation of race and class. Moengo's staff was largely foreign and white until well into the twentieth century. The executive position was invariably staffed by a Dutch person, but the Company also employed some U.S. engineers who were stationed at Moengo for a limited number of years. Some, like the well-liked Mr. Overbeck, stayed longer at their own request. In 1970, when Hesselink conducted his research, 16 of 26 staff were white (Table 7). Eight of the 16 white staff were born in the Netherlands, three in Suriname, three in Indonesia, and one in the United States and Belgium each (Hesselink 1974:67-68).

The maandgelders intermediate stratum was heavily dominated by Creoles, while the larger body of weekloners and uurloners consisted mainly of Creoles and Javanese, and a smaller number of Maroons. Casual labor gangs were largely made up of Maroons, who must have lived in the neighboring villages and some Javanese, most likely from Wonoredjo (Hesselink 1974:67-68) (see Table 7). As Hesselink argues, the presence of those categorized as Creoles in all strata masks significant social and racial differentiation that confirms rather than disproves the overlap of occupational/ social and racial hierarchies. The term Creole covers a highly diverse group in terms of class background, descent, and "color." Hesselink notes that in 1970 there was a clear difference between Creole maandgelders and weekloners and uurloners in terms of social background, which manifested itself, among other things, in the higher percentage of membership in Suriname's more elite churches and the significantly lower incidence of common-law unions among maandgelders (Hesselink 1974:73). 
Table 7. Ethnic composition of the Suralco labor force at Moengo in 1970 by rank

\begin{tabular}{|l|r|r|r|r|r|r|r|r|r|r|}
\hline \multirow{2}{*}{ Ethnic group } & \multicolumn{2}{|c|}{ Staff } & \multicolumn{2}{|c|}{ Monthly } & \multicolumn{2}{c|}{ Hourly/weekly } & \multicolumn{2}{c|}{ Total } & \multicolumn{2}{c|}{ Casual laborers } \\
\hline Creole & 8 & $31 \%$ & 76 & $79 \%$ & 328 & $35 \%$ & 412 & $39 \%$ & 15 & $7 \%$ \\
Javanese & - & & 7 & $7 \%$ & 400 & $43 \%$ & 407 & $39 \%$ & 60 & $28 \%$ \\
Hindustani & - & & 5 & $5 \%$ & 61 & $7 \%$ & 66 & $6 \%$ & 5 & $2 \%$ \\
Maroon & - & & - & - & 99 & $11 \%$ & 99 & $9 \%$ & 135 & $63 \%$ \\
Amerindian & - & & 1 & $1 \%$ & 33 & $4 \%$ & 34 & $3 \%$ & - & - \\
White & 16 & $62 \%$ & 2 & $2 \%$ & 4 & $0.4 \%$ & 22 & $2 \%$ & - & - \\
Chinese & 2 & $8 \%$ & 5 & $5 \%$ & 3 & $0.3 \%$ & 10 & $1 \%$ & - & - \\
\hline Total & 26 & $100 \%$ & 96 & $100 \%$ & 928 & $100 \%$ & 1050 & $100 \%$ & 215 & $100 \%$ \\
\hline
\end{tabular}

Source: Hesselink (1974:67).

Table 8. Marital status of inhabitants of Moengo and Paramaribo between 20 and 50 in 1950

\begin{tabular}{|l|l|c|c|c|c|}
\hline \multicolumn{2}{|l|}{$\begin{array}{l}\text { Marital Status } \\
\text { Place }\end{array}$} & Civil Wedding & $\begin{array}{c}\text { Asian } \\
\text { Marriage Act* }\end{array}$ & Cohabitating & Single \\
\hline \multirow{3}{*}{ Moengo } & Male & 46 & 9 & 29 & 17 \\
\cline { 2 - 6 } & Female & 54 & 11 & 24 & 11 \\
\cline { 2 - 6 } & Total & 50 & 10 & 26 & 14 \\
\hline \multirow{3}{*}{ Paramaribo } & Male & 31 & 10 & 20 & 40 \\
\cline { 2 - 6 } & Female & 31 & 5 & 20 & 44 \\
\cline { 2 - 6 } & Total & 31 & 7 & 20 & 42 \\
\hline
\end{tabular}

Figures based on a representative sample of 1950 census data.

* Suriname's law allows not only for civil weddings, but also for weddings concluded under the so-called Asian Marriage Act. The latter type of marriage is concluded by a Hindu or Muslim religious functionary and initially entailed conditions considered to be equivalent to ethnic or religious "common law."

These racial hierarchies are reminiscent of those at Mariënburg fifty years earlier. Shifts did occur - the disappearance of a significant European presence in the middle strata, the entry of a minority of Creoles into the staff - yet over 60 percent of the staff was still white, Creoles dominated the middle strata, while other ethnic groups made up the rank-and-file labor force. The large degree to which class and race were conflated at Moengo in part reflects differences in skills and educational level that resulted from the differential allocation of ethnic groups over Suriname's highly uneven socioeconomic terrain. Language is a good example. Sranantongo, Surinamese Creole, was the lingua franca on the work floor and in social life. Moengo's Sranantongo was specked with English expressions that pervaded work life. Higher up in 
work and social ranks, one needed both Dutch and English language skills, which disqualified many first-generation Javanese and Maroon employees. While Moengo's division of labor thus reproduced much of the conflation of class and race in society at large, it also worked to strengthen the reproduction of such racial hierarchies. In his discussion of the political economy of race in the Caribbean, Girvan (1975:13) argues that racism functioned to maintain "a large and in some cases virtually unlimited supply of unskilled, cheap, and quiescent manpower for those sectors of the expanding economy which required it." In Moengo, racial hiring also helped the Company to maintain a relatively docile workforce.

Everyday life at Moengo largely followed the Company's stratification, from housing, to a range of facilities and privileges and even social interaction. As said, in Moengo's early years residential segregation was explicitly based on race. Americans, Creoles, and Javanese were housed separately. These divisions gave way to ones based on position in the Company, which, however, remained significantly inflected by race. Moengo had separate quarters where the staff was housed in luxury villas. One step down in the hierarchy, the Company provided family houses. The lowest category of workers, weekloners and uurloners lived in smaller houses, or in bunk housing.

The system of ranked housing and distinct neighborhoods was key in the institutionalization of social divisions and hierarchies of the workspace in everyday social life. This is underscored by the ample coverage it received in my oral histories. For many, the differentiated housing represented the pervasive social divisions prevalent at Moengo, as well as the alluring possibilities for social mobility, and thereby exemplifies the ambivalent experience of Moengo's social hierarchies: a sense of discrimination, but also the promise of a higher rung on the social ladder and a better life. Take Mr. Witkamp's description: "When you go from Tonki to Suralco, you end up in Schiphol [a quarter adjacent to the airstrip, named after the main airport of the Netherlands, Schiphol]. At Schiphol you had row houses divided in compartments, and you have one such compartment. And then you can move to Bernharddorp, with houses consisting of two compartments ... and then you can go to a detached house."

Mr. Westerman, introduced above as the son of one of Tamarin's pioneers, also went on to become a Suralco employee. He concisely sketches the spatialization of class-cum-race hierarchies at Moengo.

Everyone was divided. If you were staff, you lived in the staff village. As a normal, unskilled laborer you lived at Schiphol. If you lived at Moengodorp, you were a foreman. And then you had the laborers who were a bit further than the unskilled workers, they lived at Bernharddorp. And at Julianadorp you already had those men we called gang boss, the heads, they had managerial positions but were just short of being foremen. 
So that's the way the village was divided. In that time, color also played a minor role. If you were light-skinned, you were already privileged ... People were so indoctrinated that they accepted it ... Hardly anyone complained ... What mattered to people was that they had a good life, that they could earn enough money to take care of a family and ... even build houses in the city. Those things mattered to them, so they did not have time to focus on the divisions. It was not until I was in the city that I realized that I had always lived in apartheid ... You can't go to Stafdorp. If you go to Moengodorp, you were looked at strangely by the children of the maandgelders. What is that boy from Bernharddorp doing here?

Suralco's social hierarchies were pervasive in all aspects of life in the enclave. Even resident professionals not employed by the Company were fitted into Company divisions. Higher ranks were considered staff and granted access to staff facilities; middle ranks were included in de maandgelders category. These lines were exceedingly strict, and the Company initially forbade, then discouraged fraternizing across borders (Hesselink 1974:61). A person's access to different parts of town strongly reflected occupational hierarchies at Moengo. Staff could go wherever they wished; ordinary workers were not allowed on staff village grounds, which were policed by Company police. The staff village and staff club were thus off-limits to ordinary residents, except for those who had business there, particularly maids. Even the hospital had separate departments for the three strata, and staff were given priority treatment. In keeping with the persistent differentiation common to everyday life at Moengo, staff and maandgelders would get their groceries delivered to their door and children of staff could visit a separate staff school (Hesselink 1974:54). Social and company life blended to a large extent, which meant that the hierarchical and dependency relations of the workplace were almost equally in force outside work hours and in more private spaces (see also Hesselink 1974:113-14).

A common storyline focused on the possible dire consequences of misbehaving children. Mr. Kromo, who grew up in Wonoredjo, remembers being fascinated by the staff village grounds, which were, of course, strictly off limits. "It was clean, the grass is freshly mown. There is no fence. There are flowers and green plants; to us it's a small paradise ... The workers lived in bunks, a house with two rooms. And some people have four, eight, up to sixteen children. Don't ask me how they managed." If you ventured onto Stafdorp grounds, you'd be chased off by the guards. "Only staff children are allowed to play there. If you go again, they will fetch your father ... Those children were sent to the city or to another plantation. Because if they stayed [and repeatedly got into trouble], the father was fired."

While housing was key in the institutionalization of difference, Moengo's segregated social and leisure facilities also served as the strong mechanisms 
and reminders of more generalized lines of social hierarchies and social distance in Moengo. The larger body of uurloners and weekloners could go the general recreation hall, the "Rec." The maandloners had their own club, as did the staff. The higher ranks could visit the lower-ranked club houses, the other way around was impossible. As Mr. Witkamp puts it: "You can't go to monthly club. As an uurloner, what are you going to do there? You go to the Rec, where they can come if they want. So they can descend, but you cannot climb." For many, Casa Blanca, the staff club, symbolized the difference between the staff and the rest. The luxurious staff club, an imposing white plastered building standing on a spacious lawn, was the symbol of privilege.

Aunt Es, whose family was ranked as staff after her husband had been made school principal, remembers being invited for the opening of the new Beatrix Theater in the early 1950s: "We had to sit in the box. The invitation mentioned that it was hoped that in the future we'd continue to use those reserved seats." The tenacity of rank became clear when her son, who had grown up at Moengo, finished high school in the city and came back to work in the factory for a year as a common laborer. "Well, we were seated in the box, and my son all the way up front. So we just waved to each other."

Plantation economist George Beckford (1972) likened the plantation to a total institution, an omnipotent system in which the economic system proscribes social life, and production determines community (see Khan 2010:17879). "The authority structure that characterizes the pattern of economic organization extends to social relationships," Beckford (1972:54) argues. Many of these features of the plantation as a total institution that molded social life after its production system seem to apply to the Moengo of "the early days," as many interviewees put it, illustrating the length of the shadows of the plantation at the time. Until the 1960s, Company policies and hierarchies were exceedingly rigid and significantly racially inflected, and there was no union that could counterbalance the Company's omnipotent position combining employer, landlord, constable, and judge. Everyone who lived on the plant was dependent on the Company, and so were many in Wonoredjo. Transgression of Company rules carried the ultimate sanction of immediate dismissal and removal from Moengo. However, from the 1960s onward, many of these strict regulations would become undone and the presence of a strong labor organization helped lessen the Company's omnipotence.

\section{CONTESTING SOCIAL HIERARCHIES}

"At Moengo we were all like family," I was often told, yet many people discussed how those higher up in the hierarchy had abused their position or acted arrogantly. Moengo created a contradictory matrix for social life: its isolation left people no choice but to rely on each other, yet they also had to 
deal with the Company's persistent social differentiation. The fact that work and social life at Moengo overlapped considerably resulted in recurring tensions about the extent to which work hierarchies should inform social life.

The Company sought to ensure that social relations would not interfere with work hierarchies. Company management set about to organize and differentiate social life to correspond with work hierarchies not only through the explicit ordering of Moengo proper, discussed above, but also through less public, but no less important instructions to higher personnel, most obviously in a prohibition to join the union (Hesselink 1974:63). In earlier days staff were forbidden to maintaining social contacts with non-staff, and while in 1970 that restriction was no longer in force, Hesselink notes that such socializing "was not looked upon kindly" (1974:61).

Suralco employees and retirees often argued that life in the Company and at Moengo had undergone significant changes since the 1960s. Their stories indicated a shift away from a highly arbitrary, race-based, and hierarchical management style that ruled both during and outside work hours, on and off the work floor. They recounted the slow but steady relaxation of the once exceedingly rigorous divisions that characterized all aspects of Moengo social life (from housing, to recreation, health care, and food provisioning) until the mid 1980s, when most formal divisions between staff and maandloners were revoked. Many attributed the shift away from a highly arbitrary and authoritarian management style to the slow increase in Surinamese, colored, even homegrown professional staff, as well as the influence of the union. Since the 1970s hiring and promotion practices were said to have become more meritocratic, and based on formal educational requirements and less on favoritism, color, membership in a friendly society or Court, and the mere ability to speak Dutch and English.

Since socioeconomic power in the U.S.-owned and Dutch-administrated enclave was so thoroughly intertwined with the racial division of labor, racial hierarchies were not easily challenged. The difficult renegotiation of hierarchies combining race and class came out most clearly in the recurrent discussions of the issue of white and black staff. ${ }^{18}$ Even when an official racial policy had been abandoned, Company management long remained almost exclusively white. However, from the 1960s onward, with increased opportunities for promotion within the Company and a growing number of Surinamese studying at technical universities in the Netherlands, the racial composition of Suralco's staff became more diverse. Yet racial differentiation persisted within professional staff ranks, primarily through the distinction between white and black staff.

18. The English terms white staff and black staff were invariably used. I have italicized these terms to indicate that these are the original terms. 
That there was any differentiation between white and black staff was something that some higher up in the Company hierarchy denied. They preferred to speak of senior and junior staff. For most others the racial differentiation of the professional staff was a clear reality. To them it exemplified the persistent racism at work in Company hierarchies, which they felt was also apparent in their everyday lives. Mr. Westerman remembers the division quite clearly:

They also divided the staff village. On this side, in the direction of Casa Blanca, you had only white people. Dutch, American. On the other side, you had only dark-skinned people. Black staff and white staff, it was called. What if you were a white or light-skinned Surinamese? There were some people who were white, but born in Suriname, they'd be on the [white staff] side. Really? I'm telling you. Based on the color of their skin? Yes.

With increasing numbers of Surinamese professional staff, previously strict divisions became more difficult to enforce and also caused increasing resentment, as one story about Moengo in the early 1970s illustrates. According to Mr. Thompson, a born-and-bred Moengo man and former Suralco employee:

If [Surinamese staff] had family at the plant, they were not allowed to freely socialize with them. I experienced that myself, with my uncle. $\mathrm{He}$ was staff and socialized a lot with us. At one point he had to be transferred to Paranam. Why? He was not allowed to socialize with the people of the village. But my grandma was there, three of his sisters, nephews ... He had studied with a Suralco scholarship and had only recently graduated ... After a mere three months, he had to leave. He had been warned, he said ... He shouldn't fraternize that much ... He was pressured to choose [between no longer socializing with his family and being transferred], and that's how he ended up going to Paranam.

While Company management was very much alive to the possibly dangerous relationship between work and social life, it fell upon individuals to negotiate the overlap between Company hierarchies and social relations. This became particularly difficult for those who were promoted and thus had to work out how to deal with their former equals. Disgruntlement about unfair promotions could easily sour social life. Mrs. Esajas did not have an easy time when her husband made it to staff, says her son. In smalltime Moengo, "Everything concerning work is also part of community life. So if I expect to get a job and it turns out you get it ... My wife will insult your wife on the street, at the market. So my mother has had a lot of hassles, all kinds of allegations." I further heard recurrent complaints about people who, after being promoted to the rank of maandgelder, no longer wanted to have anything to do with 
their old acquaintances. This was universally seen as a major offense. Yet, as people who had climbed up took pains to emphasize, uurloners and weekloners might also be responsible for the newly established social distance. They felt awkward visiting above their rank.

\section{THE END OF AN ERA?}

Many of the stories I heard about Moengo were nostalgic, since in 2008, when I conducted most of these interviews, the social life that was connected to mining, and the Company, had all but ceased to exist. Yet changes had already set in well before that time. Many of the workers' gains in terms of job security, wages, and social and health benefits seem to have been countermanded by a creeping disinvestment on the part of the Company. As some informants indicated, from the 1970s onward the company slowly but surely substituted its earlier role as stern paternalistic provider with that of merely an employer, getting rid of most of its extensive facilities.

By the 1980s easily accessible bauxite reserves close to Moengo were almost depleted. Moreover, military rule, which had been established in 1980, and, more generally, the decreased competitiveness of Surinamese bauxite had led to a tightening of investments from Alcoa, Suralco's mother company. ${ }^{19}$ In 1984 the company suffered losses for the first time in its history, and implemented a voluntary retrenchment plan (Lie a Kwie \& Esajas 1996:200-1). The Interior War, a prolonged armed conflict between the state/ regime and Maroon factions located in the rainforest that stretched from the mid-1980s till the early 1990 s, led to a temporary cessation of all mining activity at Moengo in 1986 and the exodus of almost all its inhabitants. When mining resumed a few months later, operations had been restructured and were managed with a significantly smaller workforce, while many parts of the production process were outsourced to labor contractors. While in 1964 only 2 percent of those active in the mining sector worked as casual laborer, between 2002 and 2006 the number of directly employed personnel went down from an already diminished 60 percent to less than 40 percent (ABS 1964, Ferrier 2007:24). Outsourcing of large parts of the production process has effectively undercut the bargaining power of organized labor. For a majority of those employed in the bauxite industry it has eliminated many of the hard-won concessions in terms of wages and other benefits, and more importantly, job security.

19. Interview with Suralco Executive Warren Pederson (2008). Lie a Kwie \& Esajas (1996:199) date Alcoa's increased reluctance to invest in its Surinamese operations to the late 1980 s. 
In the late twentieth century Moengo ceased to be a real mining town. Even after Interior War violence abated, many Moengonese stayed in the city or migrated to the Netherlands. In time, refugees from the interior who had fled to neighboring French Guyana took up residence in their vacant houses. Mines in the vicinity of Moengo had already been abandoned, but mining continued at more distant mines. At the time of my research, in 2008, the last bauxite was being mined and the Company was busy devising a rehabilitation plan for the area, but since then, plans seem to have changed. To ensure a steady input of bauxite for the alumina refinery plant at Paranam, the life expectancy of existing mines at Moengo has been extended until 2013, at which time a number of new mines in other areas should be operative. This should ensure alumina production through 2023. ${ }^{20}$ Even with the currently uncertain prospects for the large bauxite deposits in West Suriname, bauxite mining remains a crucial part of Suriname.

\section{SHADOWS OF THE PLANTATION?}

Moengo's history provides a fascinating look at Suriname's twentieth century. It recounts the rise of a new industry that drew workers away from the plantations and urban artisanal occupations to work in a massive, highly organized and orchestrated organization-cum-social community. Founded in the late 1910s Moengo developed into a thriving enclave with at its core the highly orchestrated Moengo plant, where workers were housed in different neighborhoods according to rank. In the immediate vicinity, several more informal settlements sprang up, most importantly Wonoredjo, which became home to a large number of Javanese SBM employees. The village long served as a pool of reserve labor for the Company, while it offered many facilities and services that Moengo proper lacked.

While plantation economy analyses have pointed to the reproduction of structural features of the plantation economy on account of the economic dominance of transnational mining companies, I have asked whether everyday life in the mining enclave echoed features of the plantation. It is striking that some of the mining employees came directly from the plantations or had experienced plantation society in their childhood. This links the plantation and the mine even more directly than the macroeconomic story of the concurrent decline of the plantations and the rise of the bauxite sector would lead one to suspect. Moreover, while Moengo offered myriad opportunities for advancement, it did not mean an escape from class-cum-race hierarchies that had been characteristic of the plantation. One would be tempted to con-

20. February 2010 update on Suriname's bauxite sector, http://www.bauxietinstituut. com/Bauxietsectoralg.aspx; last accessed June 8, 2010. 
clude that mining enclaves were pockets of a revamped colonial order, where largely white, and partially foreign staff lived in a closed-off compound, while a Creole intermediate stratum did most of the skilled labor. Groups that were more marginal in a socioeconomic and political sense - Javanese plantation workers and Maroons from the surrounding villages - filled the ranks of field laborers. Moengo's division of labor married class and race in persistent ways, even if these correlations were also in part the result of differences in skill and education. In time Company employment came to hold the promise of promotion, as the Company increasingly allowed for employees to move up through the ranks.

Like the plantation, the Company put a strong stamp on the social life on the part of the enclave it controlled. It moreover copied many of the disciplinary and discriminatory mechanisms of the plantation that similarly served to maintain a docile, disciplined workforce in the mine, the factory, and the workshop. Since there were few other employment possibilities, the Company had an inordinate amount of power over the lives of people in Moengo. Company hierarchies and regulations were pervasive in everyday life, and recurrent violation of its rules could lead to severe sanctions.

The organization of the labor process and makeup of the labor force strongly influenced the shape and fabric of family relations. The mining enclave and the plantation differed considerably in this respect. Moengo's almost entirely male labor force contrasts starkly with that of the plantations, where both men and women were engaged in the primary production process as individual workers. Suralco employment, the corresponding package of benefits and, more generally, the facilities and social life in the mining enclave were designed for nuclear families with a male breadwinner. The conditions of life at Moengo thus worked toward the creation of male-headed nuclear families.

Work-related hierarchies served to organize social life, which could result in the tense negotiation of social relations. How one dealt with the contradictory exigencies of persistent hierarchies and social life at close quarters in a small, isolated community was a central theme in many oral histories. This contradiction also marked what Moengo meant for many people: a highly hierarchical space where one might have felt tightly controlled and at times discriminated, but which also held the promise of a better life in the form of higher living standards and intra- and intergenerational social mobility.

The controlled site of the bauxite town long worked to reproduce the conflation of class and race, as well as the strict maintenance of social hierarchies and authority structures that were characteristic of the plantation. It, however, simultaneously molded all into a modern, almost exclusively male proletariat with a large measure of labor organization, and provided many with the means to make a better life for themselves and their children. 


\section{REFERENCES}

BECKFORD, GEORGE, 1972. Persistent Poverty: Underdevelopment in Plantation Economies of the Third World. New York: Oxford University Press.

-, 2000. The George Beckford Papers: Selected and Introduced by Kari Levitt. Mona, Jamaica: Canoe Press.

Best, Lloyd, 2005. A Model of Pure Plantation Economy. In Dennis Pantin (ed.), The Caribbean Economy: A Reader. Kingston: Ian Randle, pp. 44-57. [Orig. 1968.]

BRUIJNE, G.A., 1976. Paramaribo, stadsgeografische studies van een ontwikkelingsland. Bussum, the Netherlands: Romen.

BRUINESSEN, KLAAS, 2001. Ik heb Suriname altijd liefgehad: Het leven van de Javaan Salikin Hardjo. Leiden: KITLV Uitgeverij.

BudDINGH', HANS, 1995. Geschiedenis van Suriname. Utrecht: Het Spectrum.

BuRSIDE, W.E., 1986. The Early Years of the Suriname Bauxite Company. Suralco Magazine 18(2):3-9.

DiJCK, PITOU VAN, 2001. Continuity and Change in a Small Open Economy: External Dependency and Policy Inconsistencies. In Rosemarijn Hoefte \& Peter Meel (eds.), $20^{\text {th }}$ Century Suriname: Continuities and Discontinuities in a New World Society. Kingston: Ian Randle; Leiden: KITLV Press, pp. 48-70.

-, 2005. The Suriname Economy in a Regional Perspective. In Dennis Pantin, (ed.), The Caribbean Economy. A Reader. Kingston: Ian Randle, pp. 329-42.

ESWIN, 1956. Suriname, enige statistieken over de jaren 1931 t/m 1952. Den Haag: Economische Stichting West-Indië-Nederland.

FERRIER, DERYCK J.H., 2007. Brief Review of the Impact of the Bauxite and Alumina Industry on Financial and Socio-Economic Conditions of the Surinamese Society. Paramaribo: CESWO.

FOnTAINE, Jos, 1986. 70 Years of Bauxite Mining in Suriname. Suralco Magazine 18(2):10-27.

GIRVAN, NORMAN, 1970. Multinational Corporations and Dependent Underdevelopment in Mineral-Export Economies. Social and Economic Studies 19:490-26.

-, 1975. Aspects of the Political Economy of Race in the Caribbean and the Americas: A Preliminary Interpretation. ISER Working Paper No. 7, Institute of Social and Economic Research, University of the West Indies, Mona, Jamaica.

—, 2006. Caribbean Dependency Thought Revisited. Canadian Journal of Development Studies 27:329-52.

HeSselinK, G., 1974. De maatschappijstad Moengo en haar omgeving. Amsterdam: Geografisch en Planologisch Instituut van de Vrije Universiteit. 
Hoefte, Rosemarisn, 1998. In Place of Slavery: A Social History of British Indian and Javanese Laborers in Suriname. Gainesville: University Press of Florida.

— \& Peter MeEL, 2001. Introduction. In Rosemarijn Hoefte \& Peter Meel (eds.), $20^{\text {th }}$ Century Suriname. Continuities and Discontinuities in a New World Society. Kingston: Ian Randle; Leiden: KITLV Press, pp. xiii-xvi.

KHAN, AIsHA, 2010. Amid Memory and Historical Consciousness: Locating the Plantation Past. Journal of Historical Sociology 23(1):171-84.

Koning, ANOUK DE, 2011a. Beyond Ethnicity: Writing Caribbean Histories through Social Spaces. Latin American and Caribbean Ethnic Studies 6(3):257-79.

-, 2011b. Moengo on Strike: The Politics of Labour in Suriname's Bauxite Industry, European Review of Latin American and Caribbean Studies 91:31-47.

LEVITT, KARI \& LLOYD BEST, 1978. Character of Caribbean Economy. In G.L. Beckford (ed.), Caribbean Economy: Dependency and Backwardness. Mona, Jamaica: University of the West Indies, Institute of Social and Economic Research, pp. 34-60.

LIE A KWIE, COR J. \& HENK G. ESAJAS, 1996. 80 jaar bauxietindustrie in Suriname/80 Years of Bauxite Industry in Suriname. Paramaribo: Suriname Aluminium Company L.L.C.

OUdSCHANS DENTZ, FRED. 1921. De bauxietnijverheid en de stichting van een nieuwe stad in Suriname. De West-Indische Gids 2:481-508.

RAMSOEDH, HANS, 1990. Suriname 1933-1944: Koloniale politiek en beleid onder gouverneur Kielstra. Delft, the Netherlands: Eburon.

SCHAAIJK, M. VAN, 1975. Loonontwikkeling en nationaal loonbeleid: Een verkennende studie in opdracht van het Ministerie van Arbeid en Volkshuisvesting. Paramaribo: Ministerie van Arbeid en Volkshuisvesting.

QUAMINA, ODIDA T., 1987. Mineworkers of Guyana: The Making of a Working Class. London: Zed Books.

\section{ANOUK DE KONING}

Amsterdam Institute of Social Science Research

1012 DK Amsterdam

<anoukdekoning@yahoo.com> 